2. ibid., spec. is., 3, 65-78, 1967.

3. Organon, 4, 47-54, Warsaw, 1967.

4. Editio Cimelia Bohemica, Vol. I, Prague, 1967.

5. Sterne $u$. Weltraum, Hft $8 / 9,1968$.

6. Athens Annals of Archaelogy, No. 3, 1969.

7. Technical Annals, No. 8, Athens, 1969.

8. Oss. Astr. Capodimonte, Coll. Misc., Vol. II, No. 3, Naples, 1967.

9. Luce e Immagini, 21, 69-78, Florence, 1967.

10. Accad. Polacca della Scienze, Biblioteca a Roma, Conferenze. Fasc. 40, Wrocław-Warszawa-Kraków, 1969.

11. Rocznik Muzeum Świętokrzyskiego, Kraków, 1967.

12. Kwartalnik Historii Nauki i Techniki, 13, 397-414, Warszawa, 1968.

13. Astronomical Notices, University of Göteborg, No. 10, 3-36, Göteborg, 1968.

14. Isis, 60, 75-90, 1969.

15. Brit. J. Hist. Sci., 3, pt. 4, 293-394, 1967.

16. J. Amer. Orient. Soc., 87, 105-112, 1967.

17. Danske Videnskabernes Selskab. Mat.-fys. medd., Bol. 36, København, 1968.

18. French Historical Studies, 5, 371-404, 1968.

19. Vistas Astr., 10, 89-103, 1968, Pergamon Press.

20. Irish Astr. J., 8, 222-227.

\title{
IX. MICROFILMING OF ASTRONOMICAL MANUSCRIPTS
}

The working group for the description and microfilming of astronomical manuscripts, under the chairmanship of $\mathrm{O}$. Gingerich has been instrumental in arranging for the microfilming of the material relating to the first four Astronomer Royals at the Greenwich Observatory, viz. J. Flamsteed, E. Halley, J. Bradley and N. Bliss. This program is now complete. Attention is called to another completed microfilm of the papers of G. E. Hale, which has been prepared by the Carnegie Institution of Washington and the California Institute of Technology. The working group has been in communication with Dr. E. W. Maddison of the Royal Astronomical Society Library, who is working on a description of the astronomical manuscripts of certain English astronomers.

More detailed information on the microfilming was printed in the Information Circular No. 16 (November, 1968).

\section{JOURNAL FOR THE HISTORY OF ASTRONOMY}

Since 1970 a new journal entitled Journal for the History of Astronomy is scheduled to be published every six months in London under the editorship of M. A. Hoskin (Cambridge University). The Journal will contain surveys of the present state of knowledge in various fields of history of astronomy, reviews of new books, regular critical bibliographies, details of manuscript collections, and information of theses completed and of how access may be obtained to this material. The subject matter of the Journal will extend to allied fields, including the history of navigation, time-keeping, and geography, and the history of relevant branches of mathematics and physics.

\section{NEW BOOKS ON THE HISTORY OF ASTRONOMY}

1. Vistas in Astronomy, Vol. 9. New aspects in the history and philosophy of astronomy. (First Joint Symposium of the IAU and the Union Internationale d'Histoire et de Philosophie des Sciences, held at the University of Hamburg), 1967, Pergamon Press.

2. D. S. Evans, T. J. Deeming, B. H. Evans, S. Goldfarb (Eds.); Herschel at the Cape: Diaries and Correspondence of Sir John Herschel, 1969, University of Texas Press.

3. W. Hartner, Oriens-Occidens, Ausgewählte Schriften zur Wissenschafts- und Kulturgeschichte. Festschrift zum 60. Geburtstag, 1968, Georg Olms Verlagsbuchhandlung, Hildesheim.

4. Z. Horsky, O. Skopova, Astronomy-Gnomonics, A catalogue of instruments of the 15 th to the 19 th centuries in the collections of the National Technical Museum Prague, 1968, Prague.

5. T. N. Kary-Niyasov, The Astronomical School of Ulugh Beg (in Russian), 1967, Tachkent. 
investigations on the history of astronomy. A proposal has been made late in 1967 that the Commissions of History of Astronomy in both unions should consist of the same members. The president of Commission 41 has not been authorized to decide in that question. After the consultation with members of the organizational Committee of Commission 41 the whole question has been postponed to the Fourteenth General Assembly of IAU, when final decisions are to be taken.

During the Fourteenth General Assembly of IAU it should also be decided where the General History of Astronomy is to be published and how its Editorial Board should be organized.

E. RYBKA

President of the Commission 